\title{
The Gold Factor and Soviet Gold Industry during the Stalin Epoch
}

\author{
P. S. Grebenyuk
}

For citation: Grebenyuk P.S. The Gold Factor and Soviet Gold Industry during the Stalin Epoch. Vestnik of Saint Petersburg University. History, 2019, vol. 64, iss. 3, pp. 890-912. https://doi.org/10.21638/11701/spbu02.2019.305

The article analyzes publications and archive materials pertaining to gold mining in the context of the development of the Soviet gold industry in the 1920s - early 1950s, and demonstrates the significance of gold as a factor of the state policy. The author highlights the stages of development of the Soviet gold industry: the period of 1923-1930 was characterized by exclusive benefits provided to gold industry enterprises, and permissible private capital; the period of 1931-1945 was associated with the existence of ordinary and extraordinary sectors expressed in the activities of the two major organizations - Glavzoloto/Glavspetsmet and Dalstroy; in 1946-1953, the entire gold industry of the country was functioning under the jurisdiction of the Soviet Interior Ministry on the basis of labor mobilization of convicts. Gold was mostly produced by two entities: Glavzoloto/Glavspetsmet and Dalstroy mined 2,029.4 tonnes of gold in 1931-1950, including 1,116.2 tonnes (approximately 55\%) produced by Glavzoloto, and 913.2 tonnes (roughly $45 \%$ ) by Dalstroy. Gold was one of the few commodities which was always in demand on the global market and used in case of national emergencies and crises to correct foreign trade deficit, to guarantee foreign loans, and to procure goods which the Soviet Union was either unable to make or could not afford the cost of their production. The development of the Soviet gold industry was not determined by the estimation of loss and revenue; it was effected by the decisions made by the national governments in the late 1920s - early 1930s based on the belief in the absolute significance of gold for the functioning of Western economies.

Keywords: gold, the gold industry, Soviet gold mining, gold export, gold reserves, USSR, Glavzoloto, Glavspetsmet, Dalstroy, Soviet Interior Ministry.

Pavel S. Grebenyuk - PhD in History, Senior Researcher, North-East Interdisciplinary Scientific Research Institute of Far East Branch of the Russian Academy of Sciences, 16, Portovaya ul., Magadan, 685000, Russian Federation; grebenyuk.pavel@gmail.com

Павел Сергеевич Гребенюк - канд. ист. наук, ст. науч. сотр., Северо-Восточный комплексный научно-исследовательский институт им. Н.А.Шило ДВО РАН, Российская Федерация, 685000, Магадан, ул. Портовая, 16; grebenyuk.pavel@gmail.com

I would like to express my gratitude to Professor Vasilii Petrovich Popov from Moscow State Pedagogical University for sharing unpublished archival data of Arkhiv Prezidenta Rossiiskoi Federatsii and for comments that greatly improved the manuscript.

Я благодарю профессора Василия Петровича Попова из Московского государственного педагогического университета за то, что он поделился неопубликованными архивными данными из Архива Президента Российской Федерации, и за комментарии, которые значительно улучшили рукопись.

(c) Санкт-Петербургский государственный университет, 2019 


\section{Фактор золота и золотопромышленность СССР в сталинскую эпоху}

\section{П. С. Гребенюк}

Для цитирования: Grebenyuk P.S. The Gold Factor and Soviet Gold Industry during the Stalin Epoch // Вестник Санкт-Петербургского университета. История. 2019. Т. 64. Вып. 3. С. 890-912. https://doi.org/10.21638/11701/spbu02.2019.305

В статье проанализированы опубликованные и архивные данные о добыче золота в контексте истории развития золотопромышленности СССР в 1920-е - начале 1950-х гг., а также показано значение золота как фактора государственной политики. Развитие советской золотопромышленности в период 1923-1930 гг. характеризуется предоставлением исключительных льгот для предприятий отрасли, допуском частного капитала; период 1931-1945 гг. связан с существованием ординарного и экстраординарного секторов золотопромышленности: двух крупнейших организаций - Главзолото/Главспеццветмет и Дальстроя; в период 1946-1953 гг. вся золотодобывающая промышленность страны функционировала в системе МВД СССР и основывалась на трудовой мобилизации заключенных. Показатели промышленной добычи химически чистого золота составили в 1918-1922 гг. 29,5 т, в 1923-1930 гг. около 200 т, в 19311940 гг. - 1049 т, в 1941-1950 гг. около 1200 т. Основная часть золота была поставлена двумя организациями: в 1931-1950 гг. Главзолото/Главспеццветмет и Дальстроем было добыто 2029,4 т золота, при этом добыча Главзолото составила 1116,2 т (около 55\%), а на Дальстрой пришлось 913,2 т (около $45 \%$ ). Золото было одним из немногих товаров, всегда востребованным на мировом рынке, и использовалось в чрезвычайных для государства ситуациях и в критические периоды для корректировки внешнеторгового дефицита, гарантии иностранных кредитов и приобретения товаров, которые или было невозможно произвести самим, или которые при производстве в СССР обошлись бы крайне дорого. Развитие золотодобывающей промышленности СССР не следовало из прямой прогнозной калькуляции прибыли и убытков, а было следствием решений, принятых руководством страны в конце 1920-х - начале 1930-х гг., продиктованных памятью об экономической блокаде периода Гражданской войны, опытом Великой депрессии и верой в абсолютное значение золота для функционирования экономики западных стран.

Ключевые слова: золото, золотопромышленность, советская золотодобыча, экспорт золота, золотой запас, СССР, Главзолото, Главспеццветмет, Дальстрой, МВД СССР.

The subject of the history of the Russian and Soviet gold industry in the $20^{\text {th }}$ century has been addressed by historians more than once ${ }^{1}$. Researchers have analyzed the factor of

${ }^{1}$ Batsaev I.D. Osobennosti promyshlennogo osvoeniia Severo-Vostoka Rossii v period massovykh politicheskikh repressii (1932-1953). Dal'stroi. Magadan, 2002; Gribanova I. V. Dal'stroi: ekonomicheskoe osvoenie Severo-Vostoka SSSR v 1930-1950-kh gg. // Ekonomicheskaia istoriia. Ezhegodnik. 2009 / ed. by L. I. Borodkin. Moscow, 2009. P. 453-508; Gutak O. Ia. Zolotopromyshlennost' iuga Zapadnoi Sibiri v pervoi polovine 1920-kh gg. // Vestnik Tomskogo un-ta. Ser. Istoriia, kraevedenie, etnologiia, arkheologiia. 2003. No.276. P. 147-153; Zeliak V.G. Valiutnyi tsekh strany: istoriia razvitiia gornopromyshlennogo kompleksa Severo-Vostoka Rossii v 1928-1991 gg. Tomsk, 2015; Leshkov V. G., Bel'chenko E. L., Guzman V. V. Zoloto rossiiskikh nedr. Moscow, 2000; Makarova V.N. Zolotodobyvaiushchaia promyshlennost' Bashkortostana v period dvukh modernizatsii (80-e gg. XIX - 30-e gg. XX v.). Ufa, 2006; Mikhalevskii F. I. Zoloto v period mirovykh voin. Moscow, 1945; Sapogovskaia L. V. Chastnaia zolotopromyshlennost' Rossii na rubezhe XIX-XX vv.: Ural i Sibir' - modeli razvitiia. Yekaterinburg, 1998; Soldatov L. K. Zolotopromyshlennost' v sisteme narodnogo i mirovogo khoziaistva. Moscow, 1929; Khatylaev M. M. Zolotodobyvaiushchaia promyshlennost' Vostochnoi Sibiri: 1917-1925 gg. Iakutsk, 1983; Khrolenok S. F. Zolotopromyshlennost' Sibiri 
gold and the state policy with regard to gold industry through the lens of the development of the industry, and certain episodes of the Soviet history related to gold ${ }^{2}$. Researchers have developed a special interest in the economic efficiency of gold mining in the 1930s 1950 s, especially in comparison with other sources of precious metals ${ }^{3}$.

The theme was thoroughly explored by L. V. Sapogovskaya ${ }^{4}$ who found and processed a wide range of sources, scrutinized the gold mining policy of Russia and the Soviet Union, and examined peculiarities of the development of gold mining, and the role played by gold in the state policy. The unfinished monograph of the researcher ${ }^{5}$, prepared for publishing by her colleagues, covered a variety of issues. L. V. Sapogovskaya indicated the influence of gold mining on the formation of socioeconomic models of the national development, the state monopoly in the system of production relations, and the significance of replenishing gold reserves for the national economy.

In general, scholarly works point out that the study of the history of the Soviet gold industry remains at the stage of accumulating factual material, while nationwide and regional surveys do not embrace all problems ${ }^{6}$. Besides, an analysis of generalizing works reveals shortcomings of definitions and limited sources, which leads to a lack of critical analysis of sources used to reconstruct the achievements of gold industry. Up until now, researchers have been experiencing problems with scarcity of sources concerning such important indicators as the gold output and reserves of the Soviet Union, the replenishment of gold and forex reserves, official figures of gold exports, and use of gold resources in intelligence operations ${ }^{7}$. Historians have no knowledge of most archive materials, yet the accumulated data makes it possible to draw some conclusions in the historical and economic context of the Soviet gold policy.

(1832-1917): Ist.-ekon. ocherk. Irkutsk, 1990; Shirokov A. I. Dal'stroi v sotsial'no-ekonomicheskom razvitii Severo-Vostoka SSSR (1930-1950-e gg.). Moscow, 2014.

${ }^{2}$ Katasonov V. Yu. Zoloto v ekonomike i politike Rossii. Moscow, 2009; Kochegarova E. D. Gosudarstvennaia politika v zolotodobyvaiushchei promyshlennosti Dal'nego Vostoka Rossii (1917-1940 gody). Novosibirsk, 2011; Kuznetsov V. B. Istoriia zolotodobychi SSSR v gody Velikoi Otechestvennoi Voiny // Gornaia promyshlennost'. 2018. No.3(139). P. 102-106; Nikolaev M. G. Gosbank SSSR i “zolotaia operatsiia” 1928 g. // Ekonomicheskaia istoriia. Ezhegodnik. 2013 / ed. by L. I. Borodkin. Moscow, 2014. P.548-567; Osokina E. A. Zoloto dlia industrializatsii: “Torgsin”. Moscow, 2009.

3 Grebenyuk P.S. Ekonomicheskaia effektivnost' zolotodobychi Dal'stroia (1932-1956) // Voprosy istorii. 2017. No.9. P. 48-65; Osokina E. A. Torgsin v sovetskoi ekonomicheskoi sisteme 1930-kh gg. // Trudy instituta Rossiiskoi istorii RAN. 2013. No. 11. P. 206-226; Piliasov A. N. Trest "Dal'stroi" kak superogranizatsiia (1932-1956 gg.) // Kolyma. 1993. No. 8. P.34-37; No.9-10. P.37-41; No. 11. P.28-33.

${ }^{4}$ Sapogovskaia L. V.: 1) Zoloto v politike Rossii (1917-1921) // Voprosy istorii. 2004. No.6. P.32-47; 2) Zolotopromyshlennost' Respubliki Sovetov - SSSR - RF: evoliutsiia otrasli v al'ternativnykh sistemakh khoziaistvovaniia // Ekonomicheskaia istoriia. Ezhegodnik. 2003. Moscow, 2004. P. 266-308; 3) Zolotye resursy SSSR v voenno-ekonomicheskom protivostoianii 1939-1945 godov (postanovka problemy) // Voprosy istorii. 2005. No. 5. P.3-15.

${ }_{5}$ Sapogovskaia L. V. Natsional'naia zolotopromyshlennaia politika XVIII-XX vv., ili Nuzhno li Rossii zoloto? Ekaterinburg, 2008.

${ }^{6}$ Kochegarova E.D. Rossiiskaia zolotopromyshlennaia politika v trudakh issledovatelei // Istoricheskie, filosofskie, politicheskie i iuridicheskie nauki, kul'turologiia i iskusstvovedenie. Voprosy teorii i praktiki. 2013. No.4(30). P. 113.

7 Until recently, the same was true about statistics of Soviet non-ferrous metal output previously unknown to researchers before archives of the Soviet Central Statistical Administration were revealed and made it possible to analyse non-ferrous production dynamics and foreign trade. See: Valetov T. Ia. Tsvetnye metally v SSSR. Proizvodstvo i vneshniaia torgovlia v 1917-1966 gg. // Elektronnyi nauchno-obrazovatel'nyi zhurnal “Istoriia”. 2015. Vol. 6, iss. 8 (41). URL: http://history.jes.su/s207987840001265-0-1 (accessed: 22.11.2018). 
The article concentrates on summarizing and conducting analysis of sources of publications and archive materials regarding gold production in the Soviet Union in the 1920 s - early 1950s, and the role of gold in the Soviet state policy. The research seeks to establish the amount of industrial mining and additional sources of gold supply, the size of gold reserves, and gold exports in the indicated period. Primary objectives of the research is to establish whether gold production in the Soviet Union was economically feasible, what place the extraordinary sector of the gold industry - Dalstroy, which used convict labor, occupied in the gold production structure, what role the geopolitical, natural, and climate factors played in the economic planning of gold mining, how the gold mining economy of the Soviet Union correlated to the economy of gold mining enterprises of Western market economies, what significance gold had for foreign trade of the Soviet Union, and what role the administratively imposed ruble exchange rate played by.

For that purpose, I have studied archives of the State Institute for Planning Gold and Platinum Industry Enterprises (Giprozoloto) of the People's Commissariat of Non-ferrous MetallurgyGlavzoloto in the form of the 1944 collection of gold industry materials for 1493-1943 ${ }^{8}$. Materials of the Giprozoloto institute contain estimates of Russian and Soviet gold production volumes in the period until 1943, including technical and economic particularities of the Glavzoloto activity. It seems logical to give a review of the Soviet history of gold industry, analyze sources of the archive materials, and compare them with information from other sources.

\section{Soviet Gold industry development}

After the October Revolution, the government took control of the turnover of precious metals, nationalized gold of banks, and procured the entire gold produce. In the first years of the existence of the Soviet state, the impoundment of precious metals and other valuables from the population became a priority. The gold industry was in shambles during the Civil War; many gold mines came to a halt, and gold production declined to 14.1 tonnes in 1918, 5.1 tonnes in 1919, 2.3 tonnes in 1920, 1.8 tonnes in 1921, and 6.2 tonnes in $1922^{9}$.

The Decree on the Gold and Platinum Industry issued by the Council of People's Commissars on 31 October, 1921, formalized a number of earlier decisions and allowed all citizens of the RSFSR, cooperative associations and units (artels) to survey, prospect, and mine gold and platinum on lands of the RSFSR, and to enter into agreements with the government to operate state-owned gold and platinum enterprises and mines ${ }^{10}$. The

8 The collection was prepared by the department of the gold and platinum industry's development projects of the "Giprozoloto" institute (supervised by mining engineer V.P. Bakakin). The collection consists of a preface, two parts, and appendixes. The first part is dedicated to the Russian gold industry before 1917, the second part covers the Soviet gold industry, and the appendixes contain 82 tables and information about gold industries of the United States, Canada, and Transvaal. Glavzoloto prepared a copy of the collection for the Soviet NKVD's Dalstroy. The copy was stored by the Gosudarstvennyi arkhiv Magadanskoi oblasti (hereinafter referred as the GAMO). Sbornik materialov po zolotoi promyshlennosti 1493-1943 gg. // GAMO. F. R-23. Op. 1. D. 1542.

9 Calculated according to: Meister A.K. Obzor mineral'nykh resursov SSSR. Geologicheskii kom. Vyp. 18: Zoloto. Leningrad, 1925. P.5; "Giprozoloto" Institute archives numbers (1944) are higher than the aforesaid: $1918-21.2$ tonnes, $1919-6.5$ tonnes, $1920-4.3$ tonnes, $1921-5.2$ tonnes., $1922-$ 11.2 tonnes. - Sbornik materialov po zolotoi promyshlennosti 1493-1943 gg. L. 31.

${ }_{10}$ Sobranie uzakonenii i rasporiazhenii raboche-krest'ianskogo pravitel'stva. 1921. No. 74. St. 604. 
decree reiterated the state monopoly yet gave an impetus to gold production. The factor of gold on the foreign market created exclusive conditions for the gold industry compared to the general norms of the Soviet mining law in the context of the shift to the new economic policy.

The end of the Civil War, stabilization in the country, systematization of legislative norms, and preferential terms for gold mining made it possible to double gold production in 1922. The government's attention to problems of the gold industry was growing alongside the realization of the role of national gold production as the main source of forex metal. In the opinion of L. V. Sapogovskaya, it was then that the Soviet gold industry, its special status, preferences, and the goal of mining gold "at any cost" started to emerge ${ }^{11}$.

In the first half of the 1920s, the industry was defined by the appearance of trusts, which eventually controlled a bigger part of gold mining areas. The gold industry was allowed to have joint companies and to attract private capital, while artels and private sub-contractors could operate on the territories of state-run trusts. Private gold miners were entitled to commercial loans secured by their future products and procured equipment $^{12}$. The Main Administration of Gold and Platinum Industry of the Supreme Council of National Economy (Glavzoloto) was supervising the industry; as time passed, it acquired broad powers in the field of economic activity, procurement of equipment, materials, and food, transportation of cargo, creation of ship and motor pools, placing of orders, and preferential lending. In 1925, all gold mining enterprises were exempt from taxes, state-run enterprises paid no rent, and the rent paid by private enterprises was limited to $3 \%{ }^{13}$. Soviet gold production started increasing in 1923; it grew from 11 tonnes in 1923 to 23.9 tonnes in 1924, and reached 29 tonnes in $1925^{14}$.

The First all-Union Congress of Gold Miners held in April 1926 proposed a set of measures towards furthering the industry's growth through a combination of mechanized mining and prospecting, broader tax and customs benefits, geological survey, development of the domestic machine building industry, and training of gold industry personnel ${ }^{15}$. Yet crisis phenomena in the Soviet Union, such as the deficit of foreign trade and the fall of the Soviet chervonets (gold coins), resulted in selling of gold reserves: some 160 tonnes of gold worth of 205 million rubles were shipped abroad in $1926-1927^{16}$. These factors, in addition to a slight production decline of 1926-1928 in the principal gold supplying region of the country, the Lena area, put emphasis on the accelerated development of gold mines.

The Soviet gold industry was reorganized in 1927 with the establishment of the allUnion State Joint Stock Company, Soyuzzoloto. The company was subordinated to both the Supreme Council of the National Economy and Soviet Gosbank and concentrated assets of major gold miners (trusts and mining departments). Centralization of the industry was consistent with the course towards industrial modernization of the economy, which

\footnotetext{
11 Sapogovskaia L. V. Zoloto v politike Rossii (1917-1921). P. 44.

12 Sapogovskaia L. V. Natsional'naia zolotopromyshlennaia politika XVIII-XX vv., ili Nuzhno li Rossii zoloto? P.98.

13 Ibid. P. 103.

14 Calculated according to: Meister A.K. Obzor mineral'nykh resursov SSSR. Geologicheskii kom. Vyp. 18: Zoloto. Leningrad, 1925. P.6; Zolotopromyshlennost' SSSR (I Vsesoiuznyi zolotopromyshlennyi s'ezd). Moscow, 1927. P. 20.

15 See: Zolotopromyshlennost' SSSR (I Vsesoiuznyi zolotopromyshlennyi s'ezd). Moscow, 1927.

16 Sapogovskaia L. V. Zoloto v politike Rossii (1917-1921). P. 112.
} 
required imported equipment. Soyuzzoloto was headed by A.P. Serebrovsky, the former chair of the Azneft trust, who had an experience in implementing an industry modernization strategy and proved his ability to draw foreign capital to the Soviet oil industry ${ }^{17}$. In November 1929, a new state organization was established on the basis of Soyuzzoloto the all-Union Association for the Production, Processing, and Selling of Non-ferrous Metals, Gold, and Platinum (Tsvetmetzoloto) under the Soviet Supreme Council of National Economy, and in 1932, the gold industry became a responsibility of the Soviet People's Commissariat of Heavy Industry ${ }^{18}$. A. P. Serebrovsky became a deputy to People's Commissar G. K. Ordzhonikidze and headed the Glavzoloto Main Administration of Gold and Platinum Industry, which had control of gold mining trusts ${ }^{19}$.

Glavzoloto. Once the production was centralized, the emphasis was shifted to staterun gold production. In the early 1930s, state-run gold production was far ahead of artels, whose share had reduced from $40 \%$ in 1930 to $32.2 \%$ in $1932^{20}$. Still, the government was unable to cover the multitude of small deposits registered by the early 1930s. The government made a series of legislative amendments in 1932-1934 to formalize the legal status of prospectors, tax breaks, and full social insurance, which together with the unlimited redemption of gold mined by prospectors and a series of benefits encouraged people to mine gold ${ }^{21}$.

The gold industry experienced record investment in the middle of the 1930s. The investment in Glavzoloto amounted to 250 million rubles in 1933, 230 million rubles in 1934, 225 million rubles in 1935, 244 million rubles in 1936 and 223 million rubles in $1937^{22}$. Between 1933 and 1938, the number of hydraulic complexes increased to 179 , the number of full-cycle processing plants grew from 5 to 18 , and the number of gold dredges was up from 53 to $69^{23}$. By 1937, Glavzoloto had owned 3,168 vehicles of all types, 59 ships, and 41,200 horses. Heavy investment in the gold industry in the period of the first five-year plans, imports of hardware and vehicles, which the USSR did not make, and recruitment of foreign mining specialists resulted in large outputs.

Glavzoloto outputs grew from 31.3 tonnes of gold in 1932 to 85.5 tonnes in $1936^{24}$. The gold industry governed by Glavzoloto had 273,000 people in its employ. In 1937,

17 Kostornichenko V.N. Deiatel'nost' A.P. Serebrovskogo po modernizatsii otechestvennoi neftianoi promyshlennosti perioda NEPa: privlechenie amerikanskogo kapitala // Vestnik RUDN. Istoriia Rossii. No. 4. 2007. P. 64-71.

18 See details of changes made in the gold industry's management in: Lyskov V.M. Organy upravleniia i kontrolia gosudarstvennoi i staratel'skoi zolotopromyshlennost'iu v Rossii/SSSR (1917-1991 gg.) // Istoriko-ekonomicheskie issledovaniia. 2014. Vol.15, No.1. P. 195-214.

19 In 1932 Glavzoloto consisted of trusts Amurzoloto, Acherzoloto, Altaizoloto, Baleizoloto, Barguzinzoloto, Bashzoloto, Verkhamurzoloto, Volgozoloto, Darasunzoloto, Dzhetygarzoloto, Yeniseizoloto, Zabaikalzoloto, Zapsibzoloto, Miasszoloto, Lenzoloto, Minusazoloto, Kachkarzoloto, Tajikzoloto, Uralzoloto, Ormed, Priamurzoloto, Sevkavzoloto, Kholbonzoloto, and Yakutzoloto, as well as the Krasnoyarsk and Irkutsk machine building plants, the Moscow refinery, the Giprozoloto, Ginzoloto, and Niszolotolaboratoria institutes, and specialized agencies Zolotoprodsnab, Zolototekhsnab, Zolototrans, and Zolotorazvedka. See: Sapogovskaia L. V. Natsional'naia zolotopromyshlennaia politika XVIII-XX vv., ili nuzhno li Rossii zoloto? P. 121.

20 Sbornik materialov po zolotoi promyshlennosti 1493-1943 gg. L. 32.

${ }^{21}$ Kochegarova E.D. Gosudarstvennaia politika v zolotodobyvaiushchei promyshlennosti Dal'nego Vostoka Rossii (1917-1940 gody). P. 38.

22 Sbornik materialov po zolotoi promyshlennosti 1493-1943 gg. L. 32.

23 Ibid. L. 32.

${ }^{24}$ Ibid. L. 89. 
Glavzoloto mined 82.9 tonnes of gold, including 36.3 tonnes ( $43.9 \%)$ mined by state-run enterprises and 46.5 tonnes (56.1\%) mined by prospectors. In the period from 1936 to 1938, prospectors supplied over $70 \%$ of placer gold produced by Glavzoloto, which had 98,300 prospectors by 1938 . Attempts at transforming gold production by prospectors and stripping prospectors of multiple benefits and privileges significantly reduced their number and gold output in 1938-1939. A resolution of the Soviet Council of People's Commissars and the Central Committee of the all-Union Communist Party of Bolsheviks dated April 27, 1940, restored all former benefits and pointed out the "erroneous and wrong attitude" of the industry managers ${ }^{25}$.

In the late 1930s - early 1940s, Glavzoloto enterprises were operating across more than 4 million square kilometers, mostly in the Urals, West and East Siberia, and the Far East. During that period, Glavzoloto was developing about 200 gold mines, 1,235 placer gold deposits, and 90 dredge deposits, in addition to numerous hydraulic and mechanical sites ${ }^{26}$. Gold ore deposits were situated in the Urals (Berezovskogo, Uchalinskoye, Blagodatnoye, Kochkarskoye, Dzhetygarinskoye, Kumakskoye, etc.), Kazakhstan (Maikainskoye, Stalinskoye, Bestyubinskoye, Dzhelambatskoye, Stepnyakskoye, etc.), West Siberia (Tsentralnoye, Berikulskoye, Artemovskoye, Sovetskoye, etc.), and East Siberia (Baleiskoye, Darasunskoye, Klyuchi, etc.). There were large placer gold deposits in East Siberia and the Far East, and dredge deposits in the Urals and along the Yenisei River.

Investment in Glavzoloto enterprises started reducing in 1937 and shrank to $152 \mathrm{mil}$ lion rubles in $1941^{27}$. Investment in geological survey declined, too. During WWII, gold production in the Soviet Union plummeted because of the reduction of Glavzoloto labor force and poor supplies and logistics. In the period between 1941 and 1943, the number of workers on the public payroll reduced by $32 \%$, the number of prospectors declined by $35 \%$, and Glavzoloto's gold production fell to 37,8 tonnes by $1944^{28}$.

The gold industry's growth, which started in the late 1920s - early 1930s, resulted from such factors as the state investment program, the development of gold production by prospectors, and the increased share of gold ore deposits. Another important factor was the discovery of large fields along the Kolyma River in the country's extreme northeast, and the development of that area by the specialized government agency, Dalstroy, in the 1930s - 1950s.

Dalstroy. Dalstroy was established in 1931 as the state road and industrial construction trust in the Upper Kolyma area. In 1938, Dalstroy was handed over to the Soviet NKVD and transformed into the NKVD's Far North Construction Trust. The organization consisted of the main administration and production units, including the Northeastern Labor Camp ${ }^{29}$.

Dalstroy was operating on a vast territory of 2.8 million square kilometers and performed a huge amount of work within 25 years: geological survey alone was carried out across more than 1.9 million square kilometers. The government invested 13.7 billion ru-

${ }^{25}$ Industrializatsiia Sovetskogo Soiuza. Novye dokumenty. Novye fakty. Novye podkhody. Moscow, 1999. Part II. P. 170-173.

26 Sbornik materialov po zolotoi promyshlennosti 1493-1943 gg. L. 33.

27 Ibid. L. 32.

28 Ibid. L. 32.

${ }^{29}$ GULAG: Glavnoe upravlenie lagerei, 1918-1960. Moscow, 2000. P. 248. 
bles (in estimate prices) in Dalstroy between 1932 and $1956^{30}$. As many as 4,500 kilometers of all types of roads were built in the country's northeast, including more than 1,000 kilometers of the Kolyma highway. By the middle of the 1950s, Dalstroy had a fleet of river and sea vessels, 50 planes, 30 airports and airfields, 57 power plants, and seven factories. It had over 10,000 vehicles of all types by 1954. More than 100 schools, over 300 hospitals and first-aid stations, and about 250 clubs, cultural centers and libraries were opened in the northeast. A new town, Magadan, was built on the shore of the Sea of Okhotsk. It became the administrative center of the Magadan region established in December 1953.

Over 20 seasons between 1931 and 1950 Glavzoloto (renamed Glavspetstsvetmet in 1946) (1 $^{31}$ and Dalstroy mined 2,029.4 tonnes of gold (Tab. 1), including 1,116.2 tonnes (about $55 \%$ ) mined by Glavzoloto and 913.2 tonnes (about $45 \%$ ) mined by Dalstroy, which is an impressive amount compared to the all-Union organization, Glavzoloto.

Table 1. Gold mining by Glavzoloto/Glavspetstsvetmet and Dalstroy in 1931-1950, tonnes

\begin{tabular}{|c|c|c|c|c|c|}
\hline Years & Glavzoloto & Dalstroy & Years & $\begin{array}{c}\text { Glavzoloto/ } \\
\text { Glavspetstsvetmet }\end{array}$ & Dalstroy \\
\hline $\mathbf{1 9 3 1}$ & 28.2 & - & $\mathbf{1 9 4 1}$ & 83.3 & 75.8 \\
\hline $\mathbf{1 9 3 2}$ & 31.3 & 0.5 & $\mathbf{1 9 4 2}$ & 55.6 & 74.4 \\
\hline $\mathbf{1 9 3 3}$ & 40 & 0.8 & 1943 & 37.8 & 70.1 \\
\hline 1934 & 54.9 & 5.5 & 1944 & 42.2 & 70.4 \\
\hline 1935 & 67.8 & 14.5 & 1945 & 37.7 & 69.5 \\
\hline 1936 & 85.5 & 33.3 & 1946 & 40.4 & 52.6 \\
\hline 1937 & 82.9 & 51.4 & 1947 & 48.5 & 41.2 \\
\hline 1938 & 69 & 61.9 & 1948 & 52.9 & 43.6 \\
\hline 1939 & 63.9 & 66.3 & 1949 & 59.8 & 52.4 \\
\hline 1940 & 79.3 & 80 & $\mathbf{1 9 5 0}$ & 55.2 & 49 \\
\hline $\mathbf{1 9 3 1 - 1 9 4 0}$ & 602.8 & 314.2 & $\mathbf{1 9 4 1 - 1 9 5 0}$ & 513.4 & 599 \\
\hline
\end{tabular}

Source: Glavzoloto's gold production before 1943 as given in Sbornik materialov po zolotoi promyshlennosti... L. 89; Glavzoloto/Glavspetsmet production in 1944-1950 according to the Dokladnaia zapiska I. V. Stalinu ot 29 avgusta 1949 g. // Rossiiskii gosudarstvennyi arkhiv sotsial'no-politicheskoi istorii (hereinafter referred to as RGASPI). F. 82. Op.2. D.790. L. 17-40; Stalinskie stroiki GULAGa. 1930-1953. Moscow, 2005. P. 467; Dalstroy's gold production according to Al'bom deiatel'nosti Dal'stroia za 19321955 gody (grafiki)... L. 34 .

Since the late 1930s, Dalstroy's production had neared the indicators of Glavzoloto, and the peak of Dalstroy's output, 80 tonnes of gold, occurred in 1940. According to the table, Dalstroy played its role during the WWII, when the Glavzoloto output plummeted,

30 Calculated according to Osnovnye pokazateli razvitiia Dal'stroia za 20 let (1931-1951) // GAMO. F. R-23. Op. 1. D. 3. L. 4-5, 38-39; Album of Dalstroy's activities for 1932-1955 (graphics). D. 17b. L. 34.

31 Under the resolution of the Soviet Council of Ministers dated by September 2, 1946, Special Main Administration of the Soviet Interior Ministry Glavspetstsvetmet (SGU) was established on the basis of the Soviet Ministry of Non-ferrous Metallurgy’s Main Administration for Gold and Platinum Industry. 
while Dalstroy annually supplied approximately 70 tonnes of gold; its produce totalled 290.7 tonnes in 1941-1944. During the war, the significance of Dalstroy was demonstrated by the visit of U.S. Vice-President Henry Wallace to Magadan and Dalstroy gold mining enterprises in May $1944^{32}$. A purpose of the visit was to make sure of the gold mining capacities of the Soviet Union and to acquire information about the amount of gold production in the Soviet northeast.

In the course of the post-war economic reconstruction, the Soviet gold industry was put under the jurisdiction of the Interior Ministry in the fall of 1946. Given the substantial increase of gold production cost, the transformation of Glavzoloto into the Soviet Interior Ministry's Glavspetstsvetmet was an attempt to drastically optimize the economy of the industry e through labor mobilization of convicts, centralized management, and technical re-equipment. In the post-war period, performance indicators of Dalstroy rapidly went down, while Glavzoloto increased production in 1946-1949. Over the 1940s Dalstroy mined 599 tonnes of gold or 85.6 tonnes more than Glavzoloto/Glavspetstsvetmet.

Labor productivity of Dalstroy gold mining enterprises was nearly twice as high as in Glavzoloto but $80-86 \%$ smaller than in the United States and Canada (including production of placer gold). A comprehensive assessment of all parameters shows that labor productivity at placer gold deposits of Dalstroy (since 1957 People's Economy Council) was higher than labor productivity in most other Soviet regions, but the main factor of higher labor productivity and lower gold production cost was the higher content of gold in the alluvial. Production cost of Dalstroy gold was the lowest in the Soviet Union, but the gold content in the alluvial started reducing in 1943, and Dalstroy had to work harder to fulfill the plan year upon year and needed machines and equipment.

The remoteness and hard working conditions of many fields and the depletion of once rich deposits increased production costs. An average production cost of Dalstroy gold grew from 6.55 rubles per gram in 1940 to 13.67 rubles in 1945, and amounted to at least 25 rubles per gram in 1947-1956 ${ }^{33}$. Dalstroy's gold output dropped from 52.4 tonnes in 1949 to 44 tonnes in 1955. What is more, tin production dropped 2.5 times in 1953$1957^{34}$. In the first half of the 1950s, Dalstroy failed to maintain metal production at the previous levels. In 1954, the Dalstroy administration explained that by the events of 1953 and the loss of a great number of skilled labor force. In 1955, 25 out of 62 operating Dalstroy enterprises failed to reach plan targets ${ }^{35}$, and 32 out of 71 could not do that in $1956^{36}$. Dalstroy was transformed into the People's Economy Council of the Magadan economic administrative area in 1957.

Over the period of its activity between 1932 and 1956, Dalstroy had produced 1,187 tonnes of chemically pure gold; Dalstroy's gold production costs reached 19 billion rubles in 1932-1956, while the value of gold exceeded $\$ 1.3$ billion ${ }^{37}$. In 1932-1955,

32 Stalinskie stroiki GULAGa. 1930-1953. P. 464.

33 Calculated according to Osnovnye pokazateli razvitiia Dal'stroia za 20 let (1931-1951) L. 4-5; Album of Dalstroy's activities for 1932-1955 (graphics). L. 34 .

${ }^{34}$ Zapiska otdela partiinykh organov v TsK KPSS ot 22 noiabria 1957 g. // Rossiiskii gosudarstvennyi arkhiv noveishei istorii (RGANI). F. 13. Op. 1. D.602. L. 4.

35 Protokol i stenogramma vtoroi partiinoi konferentsii Magadanskogo oblastnogo partiinogo komiteta 18-20 ianvaria 1956// RGASPI. F. 17. Op.56. D. 1858. L. 26.

36 Svodnyi godovoi otchet za 1956 god Glavnogo Upravleniia stroitel'stva Dal'nego Severa "Dal'stroi" // Rossiiskii gosudarstvennyi arkhiv ekonomiki (RGAE). F.9022. Op. 29. D. 415 . P. 3.

37 Grebenyuk P.S. Ekonomicheskaia effektivnost' zolotodobychi Dal'stroia (1932-1956). P. 63. 
Dalstroy produced $58 \%$ of all gold in the country (excluding prospectors), and Glavzoloto mined the rest, $42 \%{ }^{38}$, which means that Dalstroy supplied slightly more than a half of all gold produced by state-run enterprises. Government investment (in every sphere of the organization's activity) and main production and financial indicators of Dalstroy's gold production are given in the Tab. 2 in prices of respective years.

Table 2. Government investment and industrial and financial indicators of Dalstroy's gold production in 1932-1956

\begin{tabular}{|l|c|c|c|c|c|}
\hline \multicolumn{1}{|c|}{ Indicators/years } & $\mathbf{1 9 3 2 - 1 9 4 0}$ & $\mathbf{1 9 4 1 - 1 9 4 5}$ & $\mathbf{1 9 4 6 - 1 9 5 2}$ & $\mathbf{1 9 5 3 - 1 9 5 6}$ & $\mathbf{1 9 3 2 - 1 9 5 6}$ \\
\hline Investment (mln rubles) & 1597 & 1851 & 5929,7 & 4327 & 13704 \\
\hline Gold production costs (mln rubles) & 1740,2 & 3544,5 & 9478,6 & 4418,2 & 19181,5 \\
\hline Gold output (tonnes) & 314,5 & 360,1 & 336,7 & 175,7 & 1187 \\
\hline $\begin{array}{l}\text { Dollar equivalent of produced } \\
\text { gold according to price set by the } \\
\begin{array}{l}\text { U.S. Department of the Treasury } \\
\text { (mln dollars) }\end{array}\end{array}$ & 353,2 & 405,1 & 378,5 & 197,5 & 1335 \\
\hline $\begin{array}{l}\text { Average dollar-to-ruble ratio by } \\
\text { production costs }\end{array}$ & $1: 4,9$ & $1: 8,7$ & $1: 25$ & $1: 22$ & $1: 14$ \\
\hline
\end{tabular}

S o u r c e: Calculated according to Osnovnye pokazateli razvitiia Dal'stroia za 20 let (1931-1951) L. 4-5, 38-39; Album of Dalstroy's activities for 1932-1955 (graphics).

Dalstroy achieved its results by developing rich placer gold deposits and using convict labor. According to published information, prison camps on the Dalstroy territory took in 859,911 convicts in the period from 1932 to $1954 ; 445,171$ convicts were released, 121,256 died, and 7,800 escaped ${ }^{39}$. The most difficult for the prisoners of the north-eastern camps of Dalstroy and the GULAG were the war years ${ }^{40}$. The Dalstroy administration directly linked the metal output to the number of convicts; the labor of prospectors cost more, and the recruitment of contractors required a lot of investment in social infrastructure and daily life, in addition to recruitment and payroll expenses. Dalstroy was part of the economic system of the NKVD-Ministry of Internal Affairs of the USSR, with all the specific features of the camp economy ${ }^{41}$. The first Dalstroy administration of E. P. Berzin planned the eventual recruitment of contractors, but after E. P. Berzin was arrested in late 1937, Dalstroy was put under the jurisdiction of the Soviet NKVD, the administration was purged, and no such proposals were made in official documents of the later period.

Hence, the achievements made by the gold industry since the early 1930s resulted from the activity of Glavzoloto and Dalstroy which represented two sectors of gold pro-

38 Stenogramma soveshchaniia po voprosam perspektivnogo razvitiia Dal'stroia ot 10 sentiabria 1956 goda. Doklad M. V. Grushi "O perspektivakh razvitiia Dal'stroia na 15-letie" // GAMO. F. P-21. Op. 5. D. 120. L.2.

39 Stalinskie stroiki GULAGa. 1930-1953. P. 538.

40 See information on conditions of detention and death-rate of prisoners: Borodkin L. I. Gulag v gody voiny // Rossiia i sovremennyi mir. 2016. No. 1(90). P. 148-158; Stalinskie stroiki GULAGa. 1930-1953. P. 411-412.

${ }^{41}$ See: Khlevniuk O. V. Ekonomika OGPU-NKVD-MVD SSSR v 1930-1953 gg.: masshtaby, struktura, tendentsii razvitiia // GULAG: Ekonomika prinuditel'nogo truda. Moscow, 2008. P. 67-89. 
duction in the Soviet Union ${ }^{42}$. Both Glavzoloto (an ordinary sector) and Dalstroy (an extraordinary sector) were established by the government and operated on official grounds; Glavzoloto was initially under the jurisdiction of the People's Commissariat of Heavy Industry, and became subordinated to the People's Commissariat of Non-ferrous Metallurgy in 1939. In 1946, all organizations and enterprises of former Glavzoloto of the Soviet Ministry of Non-ferrous Metallurgy were assigned to the Special Main Administration Glavspetstsvetmet of the Soviet Interior Ministry. Dalstroy was subordinated to the Central Committee of the all-Union Communist Party of Bolsheviks and the Soviet Council of Labor and Defense from day one, and became a main directorate of the Soviet NKVD in 1938. In March 1953, industrial units of Glavspetstsvetmet and Dalstroy were reassigned from the Soviet Interior Ministry to the Soviet Ministry of Metallurgy, while their camps were put under the jurisdiction of the Soviet Justice Ministry. The extraordinary nature of Dalstroy's operation manifested itself in the exclusive status of the organization in the Soviet administrative system, the unusual management system, and the massive use of convict labor.

Soviet gold production estimates. Glavzoloto and Dalstroy made a decisive contribution to the overall gold production in the Soviet Union, yet there were some other metal suppliers, too. Researchers still have no access to the official statistics of gold production dynamics in the Soviet Union in the late 1920s - early 1930s. There is a variety of information about particular years and periods, as well as numbers estimated on the basis of the gold production growth in percent reported by various organizations ${ }^{43}$. The publication by V. G. Leshkov mentions total amounts of Soviet gold production: according to it, 1,059 tonnes of gold were mined in the Soviet Union between 1931 and 1940; 1,390 tonnes between 1941 and 1950, and 1,180 tonnes between 1951 and $1960^{44}$.

According to the archived 1944 estimates of the State Institute for Planning Gold and Platinum Industry Enterprises (Giprozoloto), the Soviet Union produced 1,839.4 tonnes of gold over the first 20 years of its existence (Tab. 3).

Comparing information in this table and other research works, as well as the output of Glavzoloto and Dalstroy, it is possible to state that the amount of gold production cited by Giprozoloto is much bigger ${ }^{45}$, while the source does not specify the structure of the overall gold production (excluding the output of relevant organizations and people's commissariats).

Out of 1,696.6 tonnes of gold mined in 1928-1942, only 929.3 tonnes (about 55\%) were supplied by the ordinary gold mining sector - relevant organizations and people's commissariats (the People's Commissariat of Heavy Industry and the People's Commis-

${ }^{42}$ Research works described the analyzed sectors of the Soviet gold industry in different ways: official and "GULAG" (L.V.Sapogovskaya), free and enforced or special (Ye.D. Kochegarova), ordinary and extraordinary (V.G.Zelyak), civilian and convict (Ye. A. Osokina), etc.

${ }_{43}$ Zeliak V.G. Valiutnyi tsekh strany: istoriia razvitiia gornopromyshlennogo kompleksa Severo-Vostoka Rossii v 1928-1991 gg. P. 69-70; Katasonov V. Yu. Zoloto v ekonomike i politike Rossii. P. 21-22; Osokina E. A. Zoloto dlia industrializatsii: “Torgsin”. P.527-528; Sapogovskaia L. V. Natsional'naia zolotopromyshlennaia politika XVIII-XX vv. ... P. 118, 142, 153.

${ }^{44}$ Leshkov V. G. Rossiiskoe zoloto - gosudarstvennaia i staratel'skaia dobycha (1719-2007). Moscow, 2008. P. 153.

${ }^{45}$ For instance, according to Giprozoloto, Soviet gold production stood at 1,247.6 tonnes in 19311940, compared to 1,059 tonnes mentioned by V. G. Leshkov in: Leshkov V. G. Rossiiskoe zoloto - gosudarstvennaia i staratel'skaia dobycha. P.153. - See also annual output of the 1920s according to: Osokina E. A. Zoloto dlia industrializatsii: “Torgsin". P. 527-528. 
Table 3. Gold production in the USSR in 1923-1942, tonnes

\begin{tabular}{|c|c|c|c|c|c|}
\hline Years & $\begin{array}{c}\text { Soviet gold } \\
\text { production }\end{array}$ & $\begin{array}{c}\text { Relevant } \\
\text { organization } \\
\text { and people's } \\
\text { commissariats }\end{array}$ & Years & $\begin{array}{c}\text { Soviet gold } \\
\text { production }\end{array}$ & $\begin{array}{c}\text { Relevant } \\
\text { organization } \\
\text { and people's } \\
\text { commissariats }\end{array}$ \\
\hline 1923 & 20 & - & 1933 & 58.8 & 48.5 \\
\hline 1924 & 25.3 & - & 1934 & 120 & 65 \\
\hline 1925 & 25.1 & - & 1935 & 148.8 & 80.2 \\
\hline 1926 & 35.6 & - & 1936 & 161.3 & $85.5^{\star *}$ \\
\hline 1927 & 36.8 & 25.8 & 1938 & 175.8 & 91.1 \\
\hline 1928 & 53.2 & 24 & 1939 & 159.3 & 80.2 \\
\hline 1929 & 42.9 & 28.6 & 1940 & 172.7 & 96.2 \\
\hline 1930 & 42.5 & 34.3 & 1941 & 174.6 & 98.8 \\
\hline 1931 & 54.3 & 37.3 & 1942 & 135.8 & 61.4 \\
\hline 1932 & 63.5 & - & -4.1 & \\
\hline
\end{tabular}

* The document mentions the People's Commissariat of Non-ferrous Metallurgy, i.e. gold production by the Soviet People's Commissariat of Non-ferrous Metallurgy and other relevant organizations and people's commissariats operating since 1928 (Soyuzzoloto, Tsvetmetzoloto, Glavzoloto, and the Soviet People's Commissariat of Heavy Industry).

** The document says information unavailable; given the lack of information about gold production by the People's Commissariat of Heavy Industry, information is given about gold production by Glavzoloto in 1936.

S o u r c e: Based on: Sbornik materialov po zolotoi promyshlennosti... L. 31.

sariat for Non-ferrous Metallurgy), yet estimates show that Glavzoloto and its predecessors (Tsvetmetzoloto and Soyuzzoloto) had mined 786.4 tonnes of gold over that period ${ }^{46}$, which means that the remaining 142.9 tonnes were supplied by other organizations and units of the People's Commissariat for Heavy Industry between 1932-1939 and the People's Commissariat for Non-ferrous Metallurgy between 1939-1942. The total output may include ancillary mining and processing of gold-containing resources, ore, and tailings at enterprises of the people's commissariats.

What was the production structure of the remaining produce, 767.3 tonnes of gold or approximately $45 \%$ of the total output? I think most of it came from the extraordinary gold sector; Dalstroy mined 464.4 tonnes (about 27\%) between 1932 and 1942. The origin of 302.9 tonnes of gold or about $18 \%$ of the national produce remains unclear. It is possible that the information from Giprozoloto institute indicated in the column "Soviet gold production" (Tab. 3) implied not only industrial mining and refraction of gold but also other sources of the precious metal supplied to the national treasury. A bigger part of this gold may have come from the all-Union Association for Trade with Foreigners in the Soviet Territory, Torgsin (1930-1936), and from purchase of scrap gold and coins, which

\footnotetext{
46 Sbornik materialov po zolotoi promyshlennosti 1493-1943 gg. L. 89.
} 
yielded 99 tonnes of pure gold in 1932-1935 ${ }^{47}$. In the 1920s - 1930s, the Soviet State Bank was buying gold coins and pieces (jewelry, household gold items, and scrap gold) from the population, and redeeming gold from miners (including prospectors and artels). For its part, OGPU-NKVD impounded and confiscated gold from the Church and individuals.

\section{Gold as a factor of the Soviet state policy}

Gold reserve. According to publications, gold reserves of the State Bank of the Russian Empire had enlarged from 661.1 tonnes of gold in 1900 to 1,250 tonnes in $1915^{48}$. However, a considerable part of these substantial reserves were either spent or taken out of the country. L. V. Sapogovskaya mentioned the exportation of about 630 tonnes of gold from the RSFSR in 1918-1922 alone ${ }^{49}$. Judging by Ye. A. Osokina's estimates, the gold reserve of Russia had shrunk to 217.9 million gold rubles by $1922^{50}$.

Soviet gold reserves of the 1930s - 1950s constitute a problem for historians considering that the size of gold reserves and exports were classified in the early 1930s and remain inaccessible. In 1932, Gosbank's gold reserves stood at 525 tonnes $^{51}$. According to the materials published by Timothy Green in 1999, the Soviet State Bank had gold reserves of 141.3 tonnes in 1925, 375 tonnes in 1930, and 626 tonnes in $1935^{52}$. Declassified and published balances of the Soviet State Bank of 1922-1990 annual reports mentioned reserves of precious metals, which were worth of 924.2 million rubles in 1935, 2226.7 million rubles in 1940, and 2398.4 million rubles in 1950 (precious metals and foreign currency) ${ }^{53}$. Gosbank reserves served as security of cash in circulation and guaranteed fulfillment of international obligations. However, Gosbank reports reflected the actual size of Soviet gold reserves at least until 1936. In the second half of the 1930s, some of the gold was handed over to the People's Commissariat of Finance, and some was stored by NKVD ${ }^{54}$. Reserves were replenished by means of gold mining, use of tsarist coins, confiscations, and purchase from the population (Torgsin) ${ }^{55}$; some gold might have been acquired from the Baltic republics and Poland in the pre-war years. After the war, the Soviet Union was able to control production and acquire gold from Eastern Europe, China, North Korea, and Mongolia.

In 1936, the Soviet Union accepted some of the Bank of Spain's gold reserves, 510 tonnes, for storing. In 1937-1938, gold was exchanged for foreign currency to fund

${ }^{47}$ Based on calculations by: Osokina E. A. Zoloto dlia industrializatsii: “Torgsin”. P. 528.

48 Green T. Central Bank Gold Reserves: An Historical Perspective since 1845. World Gold Council Research Study. No. 23. 1999. P. 17.

49 According to the author's estimates, the country had no more than five tonnes of gold by late 1922, see: Sapogovskaia L. V. Natsional'naia zolotopromyshlennaia politika XVIII-XX vv., ili nuzhno li Rossii zoloto? P. $198,210$.

50 As of 1.02.1922, see: Osokina E. A. Zoloto dlia industrializatsii: “Torgsin”. P. 524.

51 Sapogovskaia L.V. Zolotye resursy SSSR v voenno-ekonomicheskom protivostoianii 19391945 godov (postanovka problemy). P. 3.

52 Green T. Central Bank Gold Reserves: An Historical Perspective since 1845. P. 17.

53 Balansy Gosudarstvennogo banka SSSR (1922-1990 gg.) Po stranitsam arkhivnykh fondov Tsentral'nogo Banka Rossiiskoi Federatsii. Vyp. 9. Moscow, 2010. P. 52, 120.

${ }_{54}$ Sapogovskaia L. V., Sapogovskaia L. V. Zolotye resursy SSSR v voenno-ekonomicheskom protivostoianii 1939-1945 godov (postanovka problemy). P. 3.

${ }^{55}$ Forex reserves were also replenished from other sources, see: Osokina E. A. Antikvariat (ob eksporte khudozhestvennykh tsennostei v gody pervoi piatiletki) // Ekonomicheskaia istoriia. Ezhegodnik. 2002. Moscow, 2003. P. 233-268. 
military supplies on Spain's order under existent agreements. Researchers say that Spanish gold was sold on the global market by the order of Spain, and some of the purchases were made in the USSR ${ }^{56}$. The USSR was not the only country that received a part of the gold reserves of the Bank of Spain; in the early days of the Spanish Civil War, some gold reserves of the Bank of Spain were handed over to France ${ }^{57}$.

There are different estimates of Soviet gold reserves of the 1940s - early 1950s; foreign sources roughly estimate those at 2,879 tonnes $^{58}$, yet most researchers recognize as credible the information that Soviet gold reserves stood at 2,049 in $1953^{59}$. According to archive information received by the author from V.P. Popov, as of February 1, 1948, the Soviet Union had 1,471.7 tonnes of gold in its reserves ${ }^{60}$. This is the only documentary evidence of the volume of gold reserves the Soviet Union had between the middle of the 1930s and 1953, which makes it possible to estimate the scope of Soviet gold production and exports.

Gold exports. The Soviet Union was mostly using gold as an export commodity and a factor balancing its foreign trade. The gold factor played a key role in the 1930s when the foreign trade turnover plummeted from 9176.8 million rubles in 1930 to 2666.5 million rubles in 1935, and in 1931 the foreign trade deficit grew to 1286.8 million rubles ${ }^{61}$. The foreign trade debt of the Soviet Union increased to 1400 million rubles in $1931^{62}$, the debts had to be paid, and that required a trade surplus. The national administration exported gold to adjust foreign trade indicators. In the second half of the 1930s, the government significantly improved its forex status with the increased production of gold, and Soviet export agencies and banks stopped borrowings supporting export operations.

The quantity and price of gold sold by the Soviet Union were important factors and part of the export plan. According to the CIA calculations included in official statistical materials of gold importers (Sweden, Germany, the UK, and the United States), the Soviet Union exported about 1,415 tonnes of gold (45.5 million ounces) between 1920 and 1940 ; the sum was equivalent to $\$ 1.6$ billion in the 1955 prices $^{63}$. Publications citing various sources said that most gold was exported in 1920-1922 (about 500 tonnes), 19261928 (about 200 tonnes), 1931-1934 (about 260 tonnes), and 1937 (about 170 tonnes) ${ }^{64}$.

${ }^{56}$ Howson G. Armas para España. La historia no contada de la guerra civil española. Barcelona, 2000; Kowalsky D. La Unión Soviética y la guerra civil española: una revisión crítica. Barcelona, 2003; Aceña M. El Oro de Moscú y el Oro de Berlín. Madrid, 2001; Viñas Á. El escudo de la República. El oro de España, la apuesta soviética y los hechos de mayo de 1937. Barcelona, 2007.

57 Puchsek F.Z. Istoriograficheskii mif "Kreml' v Barselone": rol' sovetskogo konsul'stva vo vremia Grazhdanskoi voiny v Ispanii // Novaia i Noveishaia istoriia. 2017. No. 1. P. 56.

58 Godek L. The state of the Russian gold industry // Europe-Asia Studies. Vol. 46. 1994. Iss. 5. P. 766.

59 Osokina E. A. Zoloto dlia industrializatsii: “Torgsin”. P. 83.

${ }^{60}$ Information by Prof. V.P.Popov, Zapiska N.A. Voznesenskomu "Svedeniia o gosudarstvennom fonde dragotsennykh metallov" [s. a.] // Arkhiv Prezidenta Rossiiskoi Federatsii (hereinafter referred to as APRF). F. 3. Op. 39. D.23. L.1.

61 Vneshniaia torgovlia SSSR za 20 let. 1918-1937 gg. Statisticheskii sbornik. Moscow, 1939. P. 10.

62 Prokopovich S. N. Narodnoe khoziaistvo SSSR. Vol. 2. New-York, 1952. P. 205.

63 Soviet Gold production, reserves, and exports through 1954. CIA Report. 1955. P.48. URL: http:// www.foia.cia.gov/sites/default/files/document_conversions/89801/DOC_0000496246.pdf (accessed: 22.11.2018).

${ }^{64}$ Osokina E. A. Zoloto dlia industrializatsii: “Torgsin”. P.71, 76-77; Sapogovskaia L. V. Natsional'naia zolotopromyshlennaia politika XVIII-XX vv.... P.112; Soviet Gold production, reserves, and exports through 1954. P. 10. 
Soviet gold exports of 1941-1954 neared 500 tonnes worth of \$557 million, including \$113 million worth of exports to the United States, $\$ 410$ million to Western Europe, $\$ 29$ million to Poland, and \$5 million to Finland ${ }^{65}$. Estimates show that gold exports did not exceed 200 tonnes in 1941-1945. During the war, the Soviet Union could not afford to assign people and equipment to the gold industry and was unable to boost production, while most imports were supplied under the lend-lease program and were limited to the capacity of operating transport corridors. The role played by Soviet gold reserves as a security of allied deliveries was crucial at the first stage of war ${ }^{66}$. Before the lend-lease agreement was signed, the United States had provided economic assistance to the Soviet Union on commercial terms, and pre-lend-lease settlements had been made in gold.

Soviet gold was mostly sold to the United States between 1941 and 1948; no official supplies from the Soviet Union were recorded in 1949-1952 yet there are unverified reports of U.S. security services on the possible selling of Soviet gold on the black market in 1949 to a total sum of $\$ 149$ million dollars. After Joseph Stalin died, the substantial foreign trade deficit of 1953-1954 was compensated with gold, and the selling of large quantities of Soviet gold began in the West in October 1953. Between October 1953 and April 1954, the Soviet Union supplied the UK, the Netherlands, France, and Switzerland with about 311 tonnes of gold worth of $\$ 250$ million to $\$ 350$ million $^{67}$. Besides, the Soviet Union used gold for settlements with Finland (1954) and Iran (1955), and granted gold loans to countries of Eastern Europe (1947-1948).

Therefore, about 2,000 tonnes of Russian gold were exported between 1920 and 1954 . The largest gold exports were seen in 1920-1922 and the initial period of industrialization; big quantities of gold were also sold in 1937 and 1953-1954. These are official amounts of gold exports, which do not include illegal export and unofficial sales, which definitely took place but could not be assessed due to the lack of information. The government used gold to support the world communist movement and intelligence operations conducted in foreign countries. On the whole, Soviet gold exports could be $10-15 \%$ higher in that period.

R. G. Pikhoya published information about the Soviet gold reserve and exports in the 1960s-1980s; according to her, the Soviet gold reserve stood at 577.1 tonnes by $1965^{68}$, which means the gold reserves had shrunk by more than $77 \%$ since the death of J.V.Stalin. It is known that 1,339.6 tonnes of gold were exported in 1963-1965 alone, and at least 707.5 tonnes of gold were sold to buy food ${ }^{69}$. The government imported grain, wool, butter, meat, and certain types of commodities.

Gold backing of the ruble and forex parity. A decree of the RSFSR All-Russian Central Executive Committee dated October 11, 1922, expressed the Soviet currency's parity in gold and set the ruble exchange rate to the dollar and other foreign currencies on the basis of their gold backing. The monetary reform of 1922-1924 set the gold backing of the ruble at the amount which was in effect before WWI, 0.774234 grams of gold. The exchange rates of foreign currencies, which had no backing established by law, depended

${ }^{65}$ Soviet Gold production, reserves, and exports through 1954. P. 56.

${ }^{66}$ Sapogovskaia L.V. Zolotye resursy SSSR v voenno-ekonomicheskom protivostoianii 19391945 godov (postanovka problemy). P. 9.

67 Soviet Gold production, reserves, and exports through 1954. CIA Report. P. 58.

68 Pikhoia R. G. Moskva. Kreml'.Vlast'. Sorok let posle voiny. 1945-1985. Moscow, 2007. P. 608.

69 Ibid. P. 608. 
on their exchange rates to the pound, the dollar, and the franc established in London, New York, and Paris. Back then, the exchange rate was 1 rubles and 94.5 kopecks to the dollar. A ban on the exportation of Soviet money and government bonds denominated in the Soviet currency was imposed, and the chervonets (gold coins) quotation at foreign exchanges stopped in 1926; the importation of foreign currencies in the Soviet Union was banned in 1928.

The dollar was devaluated and its golden backing was cut by $49 \%$ in 1933-1934; the exchange rate fell to 1 ruble 14 kopecks to the dollar. The Soviet Union conducted foreign trade transactions settlements only in a foreign currency. The actual exchange rate of the ruble drifted far away from the gold backing, and on November 14, 1935, the Soviet currency's parity for settlements was based on French francs. Starting from July 19, 1937, settlements were based on U.S. dollars at the exchange rate of 5 rubles and 30 kopecks to the dollar. Given the gold backing of the dollar, 0.888671 grams, and the exchange rate of 5 rubles and 30 kopecks to the dollar, the ruble theoretically had a gold backing of 0.167674 grams of gold. The exchange rate stayed in effect until March 1, 1950, when the Soviet ruble acquired a gold backing of 0.222168 grams of pure gold. Considering the gold backing of the ruble, a new exchange rate of 4 rubles to the dollar was established.

After the 1950 reform, the Soviet administration kept underlining the gold backing of the ruble, but it was propaganda having no effect on economic realities. During that period, the Soviet Union did not publish information about the amount of money in circulation as that would have required the simultaneous publishing of the amount of gold backing of Soviet money. The 1922 emission law required that banknotes of the Soviet State Bank be backed with gold and stable foreign currency at $25 \%$. Applicably to banknotes in circulation as of January 1, 1958, which totalled 51.1 billion rubles, the country needed gold reserves equivalent to 12.7 billion rubles or 2,842 tonnes of gold ${ }^{70}$.

The foreign exchange rate should reflect the purchasing power of a currency to one degree or another. The currency parity is based on market value of the currency in gold. History shows that official currency exchange rates might stay fixed for a long time and differ much from the actual gold backing and purchasing power. In the Soviet Union, there were both official and actual parities; the latter was closely related to the changing purchasing power of the ruble and the price of gold in the country, the actual gold backing of the ruble. As a result, foreigners were allowed to buy goods inside the USSR at an exchange rate much smaller than the official one (Torgsin); special rates were established (for embassies and consulates) ${ }^{71}$, and losses of exporters were reimbursed.

Subsidies compensating for the losses actually adjusted the currency parity and cut off excessive import profits. In case of Dalstroy and Glavzoloto, the real parity led to low purchase prices, which meant that ruble prices exceeded the official price of gold. Gold was officially sold at 5 rubles and 91 kopecks per gram, while the purchase price and the cost price of a gram of gold in 1945 was: 19 rubles and 76 kopecks and 23 rubles 41 kopecks in Glavzoloto; 6 rubles and 90 kopecks and 14 rubles and 40 kopecks in Dalstroy, and 10 rubles and 81 kopecks and 22 rubles and 39 kopecks in the case of prospectors ${ }^{72}$.

${ }^{70}$ Balansy Gosudarstvennogo banka SSSR (1922-1990 gg.) P. 93.

${ }^{71}$ In 1941-1947, there was a preferential exchange rate of 12 rubles to the dollar for foreign diplomatic missions buying rubles; the rate was fixed at 8 rubles to the dollar in December 1947.

72 Information by Prof. V.P. Popov, Zapiska A. I. Mikoiana I. V.Stalinu "O kurse rublia v inostrannoi valiute” № 533/AM ot 18 dekabria 1946 g. // APRF. F.3. Op. 39. D. 100. L. 48-60. 
According to Soviet experts, the real cost of the U. S. dollar reached 20 rubles in 1946, and the exchange rate could exceed 20 rubles from with regard to gold production cost. In the opinion of A.I. Mikoyan, such an exchange rate would have made the selling of goods on the foreign market "normally profitable". The number was mentioned in A.I. Mikoyan's note to J.V.Stalin in December 1946; it was the first proposal made in the post-war period that the country should stop fixing the ruble exchange rate on any foreign currency but again base it on gold ${ }^{73}$. The issue was topical for the Soviet administration because of the development of the international monetary system deriving from the Bretton Woods Agreement of 1944 and the Soviet Union's refusal to participate in the activity of the International Monetary Fund.

World gold price. Gold exports were insignificant in the post-war period between 1945 and 1953 because J. V. Stalin believed that the world gold prices might go up. Given the secretiveness of the Soviet Union and the absence of precise information about gold production and reserves accumulated by the late 1940s - early 1950s, the West was considering possible use of gold by the USSR as an economic weapon to lower gold prices on the global market ${ }^{74}$. However, the Soviet administration was measuring the purchasing power of gold with goods, which could be procured on global markets, and was interested in the high price of gold in the world; the price of $\$ 35$ per ounce established by the U.S. Department of the Treasury in the first half of the 1940s was deemed insufficient.

There was a free black market of gold outside the Soviet Union; there were practically no illegal transactions in the United States but in Western Europe, the Middle East, and Asia gold transactions were conducted on open markets using local currencies and U.S. dollars. The price was regularly slightly higher than the price set by the U.S. Department of the Treasury but there were also spikes in certain periods. An average gold price on European markets reached \$38-39; the highest peaks of gold prices were seen in 1949, when gold cost up to $\$ 55$ per ounce because of the re-evaluation of many currencies. Similarly, after the start of the Korean War, $\$ 44$ per ounce in January $1951^{75}$. The Soviet Union was used approximately the same range of gold prices, $\$ 42-52$, in calculations of the commission, which was preparing a report in 1949 on the necessity to stop fixing the ruble exchange rate on the dollar and to shift to the gold backing; the average global gold price was set at $\$ 45$ per ounce ${ }^{76}$. Therefore, the price established by the U.S. Department of the Treasury since the early 1940s was the minimum price on the world gold market.

Domestic consumption. Some of the gold was used on the domestic market, by industries and jewelry factories; the amounts were inconsiderable and ranged between 3 and $7 \%$ in various years. The share of gold used by industries was increasing year upon year. The government was also selling small-sized bars of gold on the domestic market. Prices on gold items purchased by the government from the population ranged between 51 rubles and 63 rubles per gram of pure gold in 1946, while state prices on gold items

73 Popov V. P. Stalinizm v chelovecheskom izmerenii: raboty raznykh let. Moscow, 2016. P. 178.

${ }^{74}$ In 1937, the Soviet Union sold \$200 million worth of gold on the global market within several months. See: Soviet Gold production, reserves, and exports through 1954. P. 10.

${ }^{75}$ Miroslav A. Kriz. The price of gold. Essays in international finance. Princeton, New Jersey. No. 15. 1952. P.3.

76 Zapiska I. V.Stalinu ot 26 marta 1949 g. ot A. Mikoiana, A. Kosygina, A.Zvereva, M. Men'shikova, V.Popova, N. Chechulina, I.Zlobina, F. Bystrova, G. Kosiachenko, V.Starovskogo // APRF. F.3. Op. 39. D. 100. L. 80. 
sold to the population ranged from 142 rubles to 170 rubles per gram ${ }^{77}$. Domestic market prices were several times higher than the state production costs. Besides, the Soviet Union had a gold black market, which flourished in the years of war and the post-war period.

\section{Conclusions}

The article analyzes publications and archives pertaining to gold production in the context of the development of the Soviet gold industry in the 1920s - early 1950s, and demonstrates the role of gold as a factor of the Soviet state policy.

Following a rise in Russia's gold output in the early $20^{\text {th }}$ century, gold production declined during WWI in 1914-1917; during the Civil War of 1918-1922, the state gold monopoly and nationalization of industries led to a plummet of gold production, and most gold mining enterprises stopped their activity. The period of 1923-1930 was characterised by the provision of exclusive benefits to gold industry enterprises, and private capital (including foreign) was allowed to operate while the government still had a monopoly on products. After the gold output stabilized, the management was centralized, and the gold industry developed in 1931-1945 because of the existence of ordinary and extraordinary sectors, two major gold mining organizations of the USSR, Glavzoloto and Dalstroy. After Glavzoloto was transformed into the Soviet Interior Ministry's Glavspetstsvetmet in 1946-1953, the entire gold industry of the country was functioning under the jurisdiction of the Soviet Interior Ministry on the basis of labor mobilization of convicts. In March 1953, industrial units of Glavspetstsvetmet and Dalstroy were reassigned from the Soviet Interior Ministry to the Soviet Ministry of Metallurgical Industry, and prison camps were passed under the jurisdiction of the Soviet Justice Ministry, but Dalstroy kept using convict labor until the late 1950s. In the 1930s-1950s, there were private prospectors alongside state-run gold mines; the attempts at reforming the institution of prospectors in various years were caused by the desire to increase the share of state-run gold production and reduce gold mining costs.

According to the Giprozoloto institute, Russia and the Soviet Union produced $2,382.8$ tonnes of gold in 1901-1940, including 805.4 tonnes in $1901-1917^{78}, 48.4$ tonnes in 1918-1922, 281.4 tonnes in 1923-1930, and 1,247.6 tonnes in 1931-1940. As mentioned before, the information about Soviet gold production given by the collection of materials in Giprozoloto included the produce of relevant organizations, people's commissariats, Dalstroy in the 1930s, and, possibly, other sources of gold. There is information that the country industrially produced 29.5 tonnes of chemically pure gold in 1918-1922, about 200 tonnes in 1923-1930, 1049 tonnes in 1931-1940, and about 1200 tonnes in 1941-1950. Between 1931 and 1950 most of the gold was supplied by two organizations, Glavzoloto/Glavspetstsvetmet and Dalstroy. They yielded a total of 2,029.4 tonnes of gold, including 1,116.2 tonnes (about 55\%) mined by Glavzoloto and 913.2 tonnes (about $45 \%)$ mined by Dalstroy. In all, Russia and the Soviet Union industrially produced over

77 Zapiska A. I. Mikoiana I. V. Stalinu “O kurse rublia v inostrannoi valiute”... L. 48-60.

78 Indicators cited by the Giprozoloto institute for 1901-1917 are based on information of gold smelting laboratories; this is not the amount of chemically pure gold, but the volume of placer gold smelted by laboratories. According to my estimates, documentary verified industrial production of chemically pure gold amounted to 682.5 tonnes in 1901-1917. See in detail: Grebenyuk P. S. Ob'emy rossiiskoi zolotodobychi v 1901-1917 gg.: istochnikovedcheskii aspekt // Vestnik arkhivista. 2018. No. 3. P. 679-691. 
3,100 tonnes of chemically pure gold in the first half of the $20^{\text {th }}$ century, but total gold supplies to the treasury, including additional sources, could amount to 3,600 tonnes.

The question of economic efficiency of gold production in Russia is closely connected to the role of money in the Soviet system and the ruble exchange rate. Gold production costs of the Soviet Union were high in the 1930s and kept growing in the subsequent periods (the 1940s and 1950s). A key reason for high gold production costs is the remoteness of Soviet deposits from industrial centers, the underdeveloped transport network, and harsh climate. Overheads always constituted a large percentage of costs. Another factor of the post-war period was the depletion of rich placer gold deposits. Since it was using gold as an export commodity, the Soviet Union was monitoring the world gold prices, which made the development of any deposits but large and rich unfeasible in the 1940s - 1950s. There were some other factors influencing gold production at play in that period, such as the increasing demand for miners and specialists in other actively developing mining areas, especially the production of uranium and non-ferrous metals, as well as ancillary gold.

After the economic shocks of WWI, most countries chose either gold or gold and forex standard. The gold standard became the international standard of the global economy crucial to international trade and transactions conducted on the world monetary and capital markets ${ }^{79}$. Gold was the money of international trade, and the turnover of international agreements and revenue and losses of such transactions were calculated on the basis of gold prices. The domestic pricing structure of the Soviet Union was detached from global market prices, and gold was used as a tender in foreign trade. The USSR had to import key commodities, such as food, machines, equipment, and key resources. It was impossible to cut the imports of those commodities below the level essential for the country; besides, they were imported irrespective of the cost. Foreign currency was necessary for imports; it was impossible to get as much foreign currency as necessary with exports, which led to a foreign trade deficit. The exchange rate would have unavoidably grown in a market economy, yet the Soviet Union established the exchange rate with administrative methods.

When options of calculating a new forex parity of the ruble were considered in 1945, a leading Soviet specialist and member of the Expert Bureau of the Soviet Gosbank Board, Z.V.Atlas, stated in a special memo that the solution should derive from purposes of the review of the ruble exchange rate. The following primary functions were mentioned: currency exchange transactions of foreigners, trans-border money transfers, Gosbank export/ import settlements with Soviet organizations, and a comparison of the cost of products in the USSR and abroad ${ }^{80}$. In the Soviet Union all of those functions were adjusted to economic realities of the socialist model so that they could ensure a more or less satisfactory parity of the Soviet ruble.

Z.V.Atlas believed it was possible to achieve a real parity on the basis of the ratio of the ruble-denominated gold price in the Soviet Union to the dollar-denominated gold price in the United States or the ratio of purchasing powers of currencies. An exchange rate based directly on the parity of purchasing powers of the ruble and the dollar would

${ }^{79}$ Mizes L. Chelovecheskaia deiatel'nost': traktat po ekonomicheskoi teorii. Cheliabinsk, 2005. P. 439444.

80 Voprosy denezhnogo obrashcheniia (1919-1982 gody) (vedomstvennye materialy) // Po stranitsam arkhivnykh fondov Tsentral'nogo Banka Rossiiskoi Federatsii. Vyp. 15. Moscow, 2014. P. 67-68. 
lead to an increase of ruble-denominated prices in the Soviet Union compared to dollar-denominated prices in the United States because of lower labor productivity rates in the Soviet Union. A parity based on the cost of gold required the calculation of an average gold price in the Soviet Union; it was possible to calculate an exchange rate more or less consistent with the purchasing price of the ruble and the dollar on the basis of the gold price in dollars.

Thus, it was advantageous to the country to maintain the existent exchange rate and annually replenish the Soviet budget with billions of rubles with markups from commercial imports; the exports of key commodities (oil, grain, and timber) ${ }^{81}$ and gold brought additional foreign currency or necessary goods and made it possible to subsidize exporters in rubles so that they made more goods. This means that the Soviet Union actually had to recognize market exchange rates. The Soviet economic model had no market economy instruments, and the production of precious metals, which broadened the range of offered loans on the global market, was an important resource of the socialist economy. In this connection, the gold potential of the Soviet Union was limited only by gold production vicissitude, the fact which the government could not control and which determined domestic prices of the socialist economy.

According to reports, the Soviet gold industry was "state-planned loss-making industry". Gold sales prices of the early 1950s reflected the ruble-to-dollar ratio of more than 40-to- 1 , while the correlation between domestic prices in the Soviet Union and the world had a 20-to-1 ratio. Economic decisions were determined by natural and climate conditions, mentioned by the authors of the Siberian Curse survey ${ }^{82}$. As far as "price of cold" is concerned, we should say that the use of convict labor in gold mining and other industries of northern districts of the USSR was based on the economic estimate and compared to the recruitment of contractors. The factor played a key role in the 1930s $-1940 \mathrm{~s} .{ }^{83}$ The "coldest" area of Dalstroy's activity had the lowest gold production costs and the highest labor productivity in the Soviet Union. The principal factors were convict labor and a high content of placer gold.

While admitting unfavorable conditions of the North, acclaimed Soviet economist S. V.Slavin, who was a deputy chairman of the Soviet Gosplan Council for the North in 1931-1934, said that Dalstroy was saving the Soviet economy a lot of money compared to the development of other gold deposits in the USSR ${ }^{84}$. This is the inside view of an expert

${ }^{81}$ See: Koleva G. Yu. Neft' v politike sovetskogo gosudarstva // Vestnik Tomskogo gosudarstvennogo pedagogicheskogo universiteta. 2016. No.9(174). P.43-50; Kondrashin V. V. Zerno v obmen na valiutu i stanki: novye dokumenty rossiiskikh arkhivov ob uchastii zapadnoevropeiskikh stran v sovetskoi industrializatsii // Klio. 2011. No.3. P. 112-115.

${ }^{82}$ Hill F., Gaddy C. The Siberian Curse: How Communist Planners Left Russia Out in the Cold. Washington, DC, 2003.

${ }^{83}$ In 1940, the year of the maximum gold output of 80 tonnes, Dalstroy spent a total of 1,732 rubles per inmate, including "the keep and the escort", which is half of spending on a contractor (4,585 rubles). An average salary of a Dalstroy contractor was 4,203 rubles per year, an average reward of an inmate was $90 \%$ smaller, about 270 rubles. Gold mining activity involved 92,100 people in 1940, including 2,900 contractors and 89,200 convicts. See: Grebeniuk P. S. Dal'stroi i proizvoditel'nost' truda v zolotodobyvaiushchei otrasli SSSR: opyt sravnitel'nogo analiza // Gumanitarnye issledovaniia v Vostochnoi Sibiri i na Dal'nem Vostoke. 2018. No. 1(43). P. 82-83. - In 1953, a Dalstroy contractor had an average annual salary of 16,677 rubles, and an inmate was paid 6, 673 rubles. See: Stalinskie stroiki GULAGa. 1930-1953. P. 411.

${ }^{84}$ Materialy Soveta po izucheniiu proizvoditel'nykh sil pri Prezidiume AN SSSR po voprosu: "Problemy razvitiia proizvoditel'nykh sil Magadanskoi oblasti” (1959 g.) // GAMO. F. P-21. Op. 5. D.714. L.22-23. 
on economic efficiency of the socialist model. The activity of Dalstroy, which supplied nearly half of all industrial gold in 1932-1956, made the average correlation between the dollar and ruble one to 12 from the angle of current gold production costs and the average world gold price, which was far bigger than the indicators achieved by the ordinary gold mining sector (Glavzoloto/Glavspetsmet) and demonstrated a high level of profitability, considering the actual parity of the ruble. While estimating the activity of Dalstroy, one should also bear in mind the rapid fulfillment of tasks, the achievements made in the development of the Extreme Northeast, and heavy investment in collecting scientific information.

The geopolitical factor of remote and border territories played a role in the development of the industry and Dalstroy's activity. J. V. Stalin was well aware of the role the discovery of gold in California played in the development of western regions of the United States, and the Soviet administration realized that the gold mining industry would give a strong impetus to the development of Siberia and the Far East. The Siberian factor in the end played an important role in the process of Soviet modernization of the economy ${ }^{85}$.

Gold had an absolute value for the Soviet administration and the Soviet economy. Gold has always been in demand on the global markets and came in handy in emergencies (1941) and crises (the first half of the 1930s) as a way to correct the foreign trade deficit, conduct current economic activity, secure international loans, and acquire goods which the Soviet Union was either unable to make or could not afford making.

Given nationalization of foreign trade and forex control, gold was a guarantee of the development of the socialist economic model, while the development of the Soviet gold industry was not defined by direct estimates of possible revenue and losses, but resulted from decisions made by the national government in the late 1920s - early 1930s; those decisions were rooted in the memory of the economic embargo of the Civil War period, the gold panic, the fear of another devastating plummet and foreign trade deficit (the experience of the Great Depression), and the belief that gold was the foundation of a normal operation of the capitalist economy.

\section{References}

Aceña M. El Oro de Moscú y el Oro de Berlín. Madrid, Taurus, 2001, 420 p.

Batsaev I. D. Specifics of the Industrial Development of the Russian Northeast in the Period of Massive Political Repressions (1932-1953). Magadan, SVKNII DVO RAN, 2002, 217 p. (In Russian)

Borodkin L. I. GULAG during the war. Rossiia i sovremennyi mir, 2016, no. 1(90), pp. 148-158. (In Russian) Grebenyuk P. S. Russian gold mining output in 1901-1917: the source study aspect. Vestnik arkhivista, 2018, no. 3, pp. 679-691. (In Russian)

Grebenyuk P.S. Economic efficiency of gold mining by Dalstroi (1932-1956). Voprosy istorii, 2017, no.9, pp. 48-65. (In Russian)

Grebenyuk P.S. Dalstroy and labour productivity in the gold mining industry of the USSR: experience of comparative analysis. Gumanitarnye issledovaniia v Vostochnoi Sibiri i na Dal'nem Vostoke, 2018, no. 1(43), pp. 78-88. (In Russian)

Green T. Central Bank Gold Reserves: An Historical Perspective since 1845. World Gold Council Research Study, 1999, iss. 23, $25 \mathrm{p}$.

Gribanova I.V. Dalstroy: the economic development of the North-East of the USSR in the 1930-1950s. Ekonomicheskaia istoriia. Ezhegodnik. 2009. Ed. by L. I. Borodkin. Moscow, ROSSPEN, 2009, pp. 453508. (In Russian)

85 Timoshenko A. I. Sibirskii faktor v formirovanii rossiiskoi industrial'noi tsivilizatsii // Ekonomicheskaia istoriia. 2013. No. 4 (23). P.23-33. 
Gutak O. Ia. The gold industry of the south of West Siberia in the First Half of the 1920s. Vestnik Tomskogo un-ta. Ser. Istoriia, kraevedenie, etnologiia, arkheologiia, 2003, no. 276, pp. 147-153. (In Russian)

Hill F., Gaddy C. The Siberian Curse: How Communist Planners Left Russia Out in the Cold. Washington, DC, Brookings Institution Press, 2003, 240 p.

Howson G. Armas para España. La historia no contada de la guerra civil española. Barcelona, Península, 2000, $464 \mathrm{p}$.

Katasonov V. Yu. Gold in Russia's economy and politics. Moscow, Ankil, 2009, 286 p. (In Russian)

Khatylaev M. M. Gold industry of East Siberia: 1917-1925. Iakutsk, Siberian branch of USSR AS, 1983, 92 p. (In Russian)

Khlevniuk O. V. Economic of OGPU-NKVD-MVD of USSR in 1930-1953: scope, structure, development trends. GULAG: Ekonomika prinuditel'nogo truda. Ed. by L. I. Borodkin. Moscow, ROSSPEN, 2008, pp. 67-89. (In Russian)

Khrolenok S.F. Gold industry of Siberia (1832-1917): historical and economic essay. Irkutsk, Irkutsk University Press, 1990, 307 p. (In Russian)

Kochegarova E. D. The State Policy and the Gold Industry of the Russian Far East (1917-1940s). Novosibirsk, SIBPRINT, 2011, 223 p. (In Russian)

Kochegarova E.D. Russian gold mining policy in research works. Istoricheskie, filosofskie, politicheskie $i$ iuridicheskie nauki, kul'turologiia $i$ iskusstvovedenie. Voprosy teorii i praktiki, 2013, no.4(30), pp.111115. (In Russian)

Koleva G. Yu. Oil in soviet politics. Vestnik Tomskogo gosudarstvennogo pedagogicheskogo universiteta. 2016. no. 9 (174), pp. 43-50. (In Russian)

Kondrashin V. V. Grain in exchange for currency and machine tools: new documents from Russian archives on the participation of Western European countries in Soviet industrialization. Klio, 2011, no.3, pp. 112-115. (In Russian)

Kostornichenko V.N. Deiatel'nost' A. P. Serebrovsky's activity in modernizing the domestic oil industry of the new economic policy's period: attraction of U.S. capital. Vestnik RUDN. Istoriia Rossii, no. 4, 2007, pp. 64-71. (In Russian)

Kuznetsov V. B. History of gold mining in the USSR during the Great Patriotic War. Gornaia promyshlennost', 2018, no. 3(139), pp. 102-106. (In Russian)

Kowalsky D. La Unión Soviética y la guerra civil española: una revisión crítica. Barcelona, Crítica, 2003, $504 \mathrm{p}$.

Leshkov V. G., Bel'chenko E. L., Guzman V. V. Russian Gold. Moscow, EKOS, 2000, 628 p. (In Russian)

Leshkov V. G. Russian Gold - produce of state and prospectors (1719-2007). Moscow, Mining book, 2008, 207 p. (In Russian)

Godek L. The state of the Russian gold industry. Europe-Asia Studies, 1994, vol.46, iss. 5, pp.757-777.

Lyskov V.M. Bodies supervising and controlling state-run and prospecting gold industry in Russia / the USSR (1917-1991. Istoriko-ekonomicheskie issledovaniia, 2014, vol. 15, no. 1, pp. 195-214. (In Russian)

Makarova V.N. The gold mining industry of Bashkortostan in the period of two modernizations (the $1880^{\text {th }}-$ the 1930s). Ufa, $20^{\text {th }}$ Century, 2006, 320 p. (In Russian)

Meister A. K. Review of Soviet Mineral Resources. Geologicheskii kom. Iss. 18: Zoloto. Leningrad, Tipografiia gos. izd. im. Gutenberga, 1925, 48 p. (In Russian)

Mikhalevskii F. I. Gold in the Period of World Wars. Moscow, Gospolitizdat, 1945, 238 p. (In Russian)

Miroslav A. Kriz. The price of gold. Essays in international finance. Iss. 15. Princeton, New Jersey, Princeton University Press, 1952, 29 p.

Mizes L. Human activity: a treatise on economic theory. Cheliabinsk, Sotsium, 2005, 876 p. (In Russian)

Nikolaev M. G. Soviet Gosbank and "gold operation" of 1928. Ekonomicheskaia istoriia. Ezhegodnik. 2013. Ed. by L. I. Borodkin. Moscow, ROSSPEN, 2014, pp.548-567. (In Russian)

Osokina E. A. Antiques (On the export of artistic treasures during the first five-year plan). Ekonomicheskaia Istoriia. Ezhegodnik. 2002. Ed. by L. I. Borodkin. Moscow, ROSSPEN, pp.233-268. (In Russian)

Osokina E. A. Gold for Industrialization: Torgsin. Moscow, ROSSPEN, 2009, 592 p. (In Russian)

Osokina E. A. Torgsin in the Soviet economic system 1930s. Trudy instituta Rossiiskoi istorii RAN, 2013, no. 11, pp. 206-226. (In Russian)

Pikhoia R. G. Moscow. The Kremlin. Power, Forty years after the war 1945-1985. Moscow, AST, 2007. 716 p. (In Russian)

Piliasov A. N. Dalstroi trust as super-organization (1932-1956). Kolyma. 1993, no. 8, pp.34-37; no.9-10, pp. 37-41; no. 11, pp. 28-33. (In Russian)

Popov V.P. Stalinism in human dimension: works of different years. Moscow, Moscow State Pedagogical University Press, 2016, 308 p. (In Russian) 
Prokopovich S. N. Soviet People's Economy. Vol.2. New York, Izdatel'stvo im. Chekhova, 1952, 358 p. (In Russian)

Puchsek F.Zh. Istoriograficheskii mif "Kreml' v Barselone": rol' sovetskogo konsul'stva vo vremia Grazhdanskoi voiny v Ispanii. Novaia i noveishaia istoriia, 2017, no. 1, pp. 56-68. (In Russian)

Sapogovskaia L. V. Private gold industry in Russia at the Turn of the $20^{\text {th }}$ Century: the Urals and Siberia Development Models. Ekaterinburg, Ural branch of RAS, 1998, 314 p. (In Russian)

Sapogovskaia L. V. Gold in Russia's policy (1917-1921). Voprosy istorii, 2004, no. 6, pp. 32-47. (In Russian)

Sapogovskaia L. V. Gold industry of the Soviet Republic, RF: evolution of the industry in alternative economic systems. Ekonomicheskaia istoriia. Ezhegodnik. 2003. Ed. by L. I. Borodkin. Moscow, ROSSPEN, 2004, pp. 266-308. (In Russian)

Sapogovskaia L. V. Gold resources of the USSR in the military and economic standoff of 1939-1945 (raising the issue). Voprosy istorii. 2005, no. 5, pp. 3-15 (In Russian)

Sapogovskaia L. V. National gold mining policy of the $18^{\text {th }}-20^{\text {th }}$ centuries or does Russia need gold? Ekaterinburg, Ural branch of RAS, 2008, 328 p. (In Russian)

Shirokov A. I. Dalstroi in socioeconomic development of the Soviet northeast (1930s - 1950s). Moscow, ROSSPEN, 2014, 654 p. (In Russian)

Soldatov L. K. The gold industry in the system of national and global economy. Moscow, Soiuzzoloto, 1929, 110 p. (In Russian)

Timoshenko A. I. The gold industry in the system of national and global economy. Ekonomicheskaia istoriia, 2013, no. 4 (23), pp. 23-33. (In Russian)

Viñas Á. El escudo de la República. El oro de España, la apuesta soviética y los hechos de mayo de 1937. Barcelona, Crítica Publ., 2007. 734 p.

Zeliak V. G. The Country's FOREX Shop: History of the Gold Mining Complex of Northeastern Russia in 19281991. Tomsk, Tomsk State University Press, 2015, 466 p. (In Russian)

Статья поступила в редакцию 28 ноября 2018 г.

Рекомендована в печать 10 июня 2019 г.

Received: November 28, 2018

Accepted: June 10, 2019 